\title{
Obituary
}

Prof. J. E. A. Steggall

$\mathrm{P}^{\mathrm{F}}$ ROF. JOHN EDWARD ALOYSIUS STEGGALL died in Dundee on November 26. He was born in London on November 19, 1855, the son of Dr. J. W. B. Steggall, a physician whose family came from East Anglia, and from whom he inherited a love of architecture. $\mathrm{He}_{e}$ was educated under the wellknown headmaster, Dr. Abbott, at the City of London School, and afterwards at Trinity College, Cambridge, where in 1877 he gained the Sheepshanks Medal for astronomy and in the next year graduated second wrangler, Hobson being senior. After taking the first Smith's prize, Steggall taught for a few terms at Clifton College (1878-79), next at Owens College, Manchester (1880-83), and in 1883 was appointed to the chair of mathematics and natural philosophy at the newly founded University College of Dundee. The responsibility of shouldering the work of two separate departments was considerable: and when in 1895 a redistribution was made, he continued as professor of pure and applied mathematics until he retired in 1933, after attaining the jubilee year of his work in the Dundee post.

Steggall was a brilliant mathematician who carried far into the twentieth century that adaptability and gift for problem solving which used to be such a feature in the training for the Cambridge Mathematical Tripos. The present less spectacular, but more solid, methods which lay the foundations for prolonged research were searcely encouraged in those days, and later the full time-table of the early years at Dundee left little opportunity for embarking on such a course. Yet the papers which Steggall wrote for the Edinburgh Mathematical Society show an incisive neatness revealing no mean artistic power. His chief interests were in the theory of numbers and kinematical geometry. He was an exceptionally good examiner who maintained an alertness and freshness of outlook to the end.

Steggall was an admirable colleague, and with his students he was popular. One who is now a professor of engineering writes: " $\mathrm{He}$ sparkled in the many branches of learning which his facile genius enabled him to pursue. He was at home in physics and mathematics, a connoisseur in music and in artmore than a dilettante in architecture-whatever he touched he adorned. . . . It must have been difficult for an intellect such as his to break down the stores of knowledge into fragments suited to our powers of assimilation. He exercised on us his wit, but, though sometimes caustic, it was never used to humiliate. His encouragement was vitalizing".

Steggall's collection of books and engravings, his delicate pen sketches of architectural detail and spreading mountain form, his mathematical models and his craftsmanship in woodwork and photography reveal many interests. He was a keen cyclist, and when close on seventy years of age rode the five hundred miles from Dundee to Cardiff to attend the meeting of the British Association. He was a buoyant and entertaining holiday companion.

At Dundee Steggall took an active interest in college, city and church : and as a scientific worker he insisted on the importance of fostering the classical and artistic side of education at a college set in a large industrial city. In 1878, he married Isabella Katherine, the sister of Sir James Frazer (his college friend at Trinity, Cambridge, who was second classic in the same year of graduation). $\mathrm{He}$ is survived by his wife and two daughters. His only son, who was an officer in the Royal Navy, was killed at the Battle of Jutland in 1916.

On vacating his chair in 1933, Steggall received. the honorary degree of LL.D. of the University of St. Andrews. He was also an honorary associate of the Royal Institute of British Architects. An outstanding figure in the life of the youngest college of the University of St. Andrews has passed on.

H. W. T.

\section{Prof. Erich von Hornbostel}

THe death of Prof. Erich von Hornbostel at Cambridge on November 28 is a great loss to the small body of students of comparative music. He was born in Vienna fifty-eight years ago. After specialising in chemistry at the Universitios of Vienna, Heidelberg and Berlin, he settled in Berlin where in 1901 he began his studies in physiology, psychology, anthropology and ethnology, which laid the founda. tion of his life's work in 'musicology', as the Germans term it. With Stumpf and Abraham, he began in 1903 to collect and to analyse phonographic and gramophone records of primitive music, accurately determining the pitch of the notes sung and of the musical instruments employed. He was able to show that the pan-pipes and the harmonica, despite their wide wanderings, retain the same pitch, the former in Melanesia and Brazil, the latter in Burma and Africa. He ascribed this remarkable constancy in part to the influence of the memory of absolute pitch in primitive man.

Von Hornbostel worked also on the affinities of Sumerian, Chinese and similar early cultures in other directions, and at the time of his death was engaged in discovering the basis of certain forms of African symbolism. He devised a theory of consonance in music and he carried out valuable investigations into the binaural localisation of sounds, formulating the now favourite hy pothesis which is based on the time-relations of the sound reaching each ear. He also conducted, with the assistance of pupils, researches upon smell, dealing particularly with certain psychological characters which he believed to be analogous to those found in other senses. 
Under Hornbostel's care, direction and generosity, the now famous Berlin 'Archives' of primitive music grew so that ultimately it comprised about 10,000 records. This he presented to the University, which conferred on him the rank of professor. Being a non-Aryan (his mother was a Jewess, related to the well-known banking family of Warburg in Hamburg), he was compelled to leave Berlin in 1933. He was at once offered a post at the new School of Social Research in New York. But never a man of strong physique, he succumbed, after spending a few months there, to a severe cardiac lesion, and was advised to exchange the climate of New York for that of England. $\mathrm{He}$ arrived here in a critical condition from which he made only a partial recovery. His financial means had at one time been considerable, but he arrived with his wife in England almost penniless. $\mathrm{He}_{\Theta}$ received much help from the Academic Assistance Council, and spent the last few months of his life happily in Cambridge, where he was able to resume his musical and ethnological studies.

Prof. von Hornbostel was a man of unusually wide interests and culture, who endeared himself to all with whom he came into contact. He was an ardent and original worker and a great enthusiast in the application of scientific methods to psychological and ethnological problems. His only son is working in physies at New York.

C. S. M.
We regret to announce the death on September 28 at the age of seventy-two yoars of Prof. Ernest Gérard, honorary professor of the Lille faculty of medicino and pharmacy, corresponding national member of the French Academy of Medicine and Society of Pharmacy and knight of the Legion of Honour. He qualified in 1887, and after acting as lecturer in pharmacy at Paris and Toulouse, he was appointed professor at Lille in 1902. He is best known for his work on fatty acids, fermentation and the role of cholesterol in health and disease. $\mathrm{He}$ was the author of a manual of galenic pharmacy, manipulations in pharmacy, the technique of sterilisation, a treatise on the urine, and a practical work on the analysis of food stuffs.

WE regret to announce the following deaths :

Miss Marian Frost, librarian and curator of the Public Library, Museum and Art Gallery, Worthing, on December 27.

Prof. Victor Grignard, professor of general chemistry in the University of Lyons and an honorary fellow of the Chemical Society, on December 13, aged sixty-four years.

Prof. Vassil Zlatarski, professor of Bulgarian history in the University of Sofia, an authority on Byzantine culture, on December 16, aged seventy years.

\section{News and Views}

\section{New Year Honours}

The New Year honours list contains the following names of men of science and others associated with scientific work and interests : Knights : B. C. Burt, agricultural expert to the Imperial Council of Agricultural Research; H. B. Devine, for services to surgery in the State of Victoria; Prof. A. Harden, emeritus professor of biochemistry, University of London; Dr. H. J. W. Hetherington, vice-chancellor of the University of Liverpool ; Dr. Humphrey Milford, publisher to the University of Oxford; Prof. D. P.D. Wilkie, professor of surgery at the University of Edinburgh, member of the Medical Research Council ; C.B. : A. Humphries, late chief mechanical engineer and superintendent, Building Works, Engineering Department, Royal Arsenal, Woolwich; C.M.G.: Willi Fels, for services to ethnology in the Dominion of New Zealand; A. C. Barnes, director of agriculture, Jamaica; G. T. MeCaw, civil assistant, War Office, for services in connexion with surveys in the Colonies ; H. R. Montgomery, chief native commissioner, Kenya; W. Nowell, director of the East African Agricultural Research Station; C.I.E. : R. G. Allan, director of agriculture, United Provinces, India; E. A. Wraight, metallurgical inspector, Jamshedpur ; C.B.E. : J. N. Cameron, director of the Department of Agriculture, Sudan Government ; Lieut.-Colonel A. MacD. Dick, professor of ophthalmology, King Edward Medical College, Lahore, Punjab; Dr. P. Hartley, director of the Department of Biological Standards, Medical Research Council ; J. F. Marshall, honorary director of the British Mosquito Control Institute, Hayling Island; A. J. Martin, assistant comptroller, Patent Office, Board of Trade ; O.B.E. : Dr. S. S. Bhatnagar, professor of physical chemistry and director, University Laboratories, Punjab University ; T. Crook, principal of the Mineral Resources Department, Imperial Institute; Dr. R. W. Dodgson, director of shellfish services, Ministry of Agriculture and Fisheries ; F. A. A. Hart, forest adviser, Eastern States Agency; G. E. Holden, technical adviser to the Dyestuffs Advisory Licensing Committee; Dr. N. R. Junner, director of the Geological Survey, Gold Coast ; E. MacDonald, conservator of forests, Sierra Leone; F. Rayns, director of the Norfolk Agricultural Station; Capt. A. T. A. Ritchie, game warden, Kenya ; H. L. Stevens, principal scientific officer, Air Ministry; T. Waites, Government statistician, State of New South Wales; M.B.E.: T. Close, agricultural machinery officer, Ministry of Agriculture and Fisheries; R. R. Glanville, agricultural officer, Sierre Leone; A. F. B. Hull, for services to natural history in the Commonwealth of Australia. 